\title{
Benefícios fiscais e gasto tributário no ICMS, espécies e métodos de mensuração
}

\author{
Tax benefits and tax expenditures in ICMS, types \\ and measurement methods
}

\section{Rodrigo Frota da Silveira ${ }^{1}$ Michel André Bezerra Lima Gradvohl²}

\section{RESUMO}

Tendo em vista o elevado gasto tributário anual dos estados brasileiros e do Distrito Federal referentes a benefícios fiscais concedidos com base no ICMS, resulta a necessidade de mensurar adequadamente estes valores e controlar os seus resultados. A complexidade e diversidade da legislação tributária e dos benefícios relativos ao ICMS têm sido fortes empecilhos à construção de modelos adequados a mensurar tais renúncias fiscais. Este estudo tem por objetivo identificar, por meio de pesquisa qualitativa, espécies de benefícios fiscais com este imposto e desenvolver metodologias capazes de mensurar o montante de recursos públicos renunciados em cada modalidade identificada. O método aplicado foi a busca da Constituição e Leis Complementares no site do planalto e da legislação do ICMS, nos sites das administrações tributárias estaduais. Após a leitura, foram selecionadas apenas as normas referentes a benefícios fiscais. A pesquisa identificou padrões, divididos em famílias, gêneros e espécies, de benefícios fiscais com ICMS, assim como descreveu métodos de quantificação dos valores renunciados em cada modalidade. Os resultados obtidos são um primeiro passo no caminho para desenvolver uma metodologia que possibilite aos órgãos de controle aferir a relação de custo-benefício de cada modalidade de benefício deferido.

\footnotetext{
1 Graduado em direito e administração, mestre em administração pela FEA/USP, auditor tributário, professor, pesquisador, membro do conselho Técnico da Febrafite. E-mail: rodrigofsilveira@gmail.com

2 Doutor em ciências jurídicas e sociais, auditor fiscal da receita estadual, conselheiro do Contencioso Administrativo Tributário, do Conselho de Defesa dos Contribuintes e do Conselho Gestor do Fundo de Direitos Difusos do Estado do Ceará, professor e pesquisador. E-mail: miche.andre07@gmail.com
} 
Palavras-Chave: Gasto Tributário. Benefícios Fiscais. ICMS. IVA. Modalidades. Aferição.

\section{ABSTRACT}

In sight of the great annually tax expenses by the Brazilian States and the Federal District referring to tax benefits given with ICMS, ensues the necessity to control its results. The legislation complexity and diversity around this tribute and benefits has been a strong obstacle to the construction of adequate models to measure such tax waivers. This study aims to identify, through qualitative research, tax benefits models with this tax, and also aims to develop methodologies capable of measuring the amount of public resources waived in each identified modality. The method applied was the search for the Constitution and Complementary Laws on the website of the plateau palace and for the ICMS legislation, on the websites of the state tax administrations. After reading, only the rules regarding tax benefits were selected. The research has identified patterns and developed a classification system, considering characteristic and peculiarities of tax benefits with ICMS, and has described quantification methods of the waived values in each modality. The results obtained are a first step in the path to develop a methodology that allows control organizations to measure the relation of cost-benefit of each given benefit modality.

Keywords: Tax Expenditures. Tax Benefits. ICMS. VAT. Modalities. Measurement.

Recebido: 03-09-2020

Aprovado: 07-10-2020

\section{INTRODUÇÃO}

Benefícios fiscais, também identificados como renúncias fiscais, relativos ao ICMS, podem ser descritos e analisados de diversas formas. 
Neste artigo, vamos analisá-los pela ótica jurídica, passando pela Constituição Federal e leis complementares, entre outras normas, e pela ótica econômica, passando pela carga tributária suportada pelo sujeito passivo ou pelo canal de distribuição. Veremos que alguns dispositivos normativos relativos ao ICMS podem ser considerados benefícios fiscais do ponto de vista jurídico, mas do ponto de vista econômico podem ser considerados "malefícios" fiscais. Por outro lado, alguns dispositivos normativos podem significar um benefício do ponto de vista econômico, mas do ponto de vista jurídico podem estar escritos de forma a não ser facilmente percebido o favor fiscal concedido.

Vamos utilizar neste artigo o conceito de gasto tributário de ICMS, como o desvio em relação à estrutura básica do tributo, instituído pela legislação estadual, que permite ao sujeito passivo ou ao canal de distribuição, desde a produção até a saída ao consumidor final, pagar um valor menor a título de ICMS, em comparação ao que seria devido, considerando a estrutura básica do imposto (PELLEGRINI, 2014).

Conforme dados do Boletim de Finanças dos Entes Subnacionais ${ }^{3}$, elaborado pela Secretaria do Tesouro Nacional, relativos ao ano de 2019, baseados nas informações disponibilizados pelas Secretarias de Fazenda dos Estados, os governos estaduais deixaram de arrecadar 91,7 bilhões de reais em decorrência de renúncias fiscais relativas a tributos estaduais.

A relevância econômica desse gasto tributário para as contas dos Estados e para as contas nacionais justifica o esforço para desenvolver uma metodologia específica para o cálculo das renúncias relativas ao ICMS, o tributo de maior importância para os Estados, que seja aplicável a todos os Estados, propiciando que os valores sejam corretamente apurados nos diversos entes e gerando a possibilidade de comparar os resultados obtidos em cada Estado.

No intuito de dar o primeiro passo no árduo caminho para desenvolver essa metodologia, objetivamos neste trabalho identificar, nas diversas 3 
e complexas legislações estaduais sobre ICMS, modelos de deferimento de benefícios fiscais com esse imposto, assim como desenvolver metodologias capazes de mensurar o montante de recursos públicos renunciados em cada modalidade identificada.

\section{TIPOS DE BENEFÍCIOS FISCAIS DE ICMS PREVISTOS NA LEGISLAÇÃO NACIONAL}

A Constituição Federal brasileira de 1988 trata de benefícios fiscais de forma ampla no artigo $150, \S 6^{\circ}$, quando estabelece que quaisquer subsídios, isenção, redução de base de cálculo, concessão de crédito presumido, anistia ou remissão, relativos aos impostos, às taxas ou contribuições, só poderão ser concedidos mediante lei específica, Federal, Estadual ou Municipal, que regule exclusivamente as matérias acima enumeradas ou o correspondente tributo.

A Constituição trata de benefícios fiscais relativos ao ICMS, no artigo $155, \S 2^{\circ}$, quando fixa regras relativas à isenção de ICMS, que pode ser com ou sem a manutenção dos créditos relativos às operações anteriores, quando determina que a priori a alíquota interna do ICMS não pode ser inferior à alíquota interestadual, quando prevê que o ICMS não incide sobre exportações e quando estabelece que compete a Lei Complementar Nacional regular a forma como, mediante deliberação dos Estados e do Distrito Federal, isenções, incentivos e benefícios fiscais serão concedidos e revogados. Desse conjunto de regras, podemos extrair duas considerações iniciais:

1 - A competência dos Estados para instituir o ICMS é limitada por disposição constitucional, tanto no que se refere ao campo de incidência do imposto como em relação às questões intrínsecas à regra de incidência do imposto, existindo, por exemplo, limitação na fixação de alíquotas;

2 - O ICMS pode ser objeto de benefício fiscal concedido pelos Estados, todavia, a forma de conceder esses benefícios é restrita, sendo 
exigido acordo entre os Estados e veiculação por lei específica do Estado competente.

A Lei Complementar $\mathrm{n}^{\circ}$ 87, de 13 de dezembro de 1996, que dispõe sobre o ICMS, não trata de benefícios fiscais desse imposto no que se refere à concessão e aos tipos de benefícios possíveis, mas trata do efeito desses benefícios. Em especial, trata dos efeitos da isenção na apuração do imposto devido e no crédito relativo às operações anteriores ${ }^{4}$.

A Lei Complementar $\mathrm{n}^{\circ}$ 24, de 07 de janeiro de 1975, que dispõe sobre os convênios para a concessão de isenções do ICMS, por outro lado, identifica algumas espécies de benefícios fiscais de ICMS, além de descrever o processo mediante o qual os Estados, em conjunto, podem permitir que determinado benefício possa ser concedido por um ou alguns Estados. Dentre os benefícios citados nessa Lei, temos:

1 - Isenção;

2 - Redução de base de cálculo;

3 - Devolução total ou parcial do tributo;

4 - Incentivos fiscais ou financeiros fiscais, que resultem em redução ou eliminação do respectivo ônus.

A Lei Complementar $\mathrm{n}^{\circ}$ 101, de 4 de maio de 2000, que estabelece normas de finanças públicas voltadas para a responsabilidade na gestão fiscal, conhecida como Lei de Responsabilidade Fiscal - LRF, não trata de benefícios fiscais especificamente em relação ao ICMS, mas ao tratar do tema Renúncia de Receitas, aborda o assunto de forma ampla e exige, entre outras condições, que a concessão ou ampliação de incentivo ou benefício de natureza tributária, da qual decorra renúncia de receita, deve estar acompanhada de estimativa do impacto orçamentário-financeiro no exercício em que deva iniciar sua vigência e nos dois seguintes. Em seguida, a LRF define que a renúncia compreende:

4 Vide por exemplo, os $\S \S 1^{\circ}$ e $3^{\circ}$ do artigo 20: [...] não dão direito a crédito as entradas de mercadorias ou utilização de serviços resultantes de operações ou prestações isentas ou não tributadas [...], e é vedado o crédito relativo à mercadoria entrada no estabelecimento [...] quando a saída do produto resultante não for tributada ou estiver isenta do imposto, exceto se tratar-se de saída para o exterior. 
1 - Anistia;

2 - Remissão;

3 - Subsídio;

4 - Crédito presumido;

5 - Concessão de isenção em caráter não geral;

6-Alteração de alíquota, que implique redução discriminada de tributos;

7 - Modificação de base de cálculo, que implique redução discriminada de tributos;

8 - Outros benefícios que correspondam a tratamento diferenciado.

\section{A CLASSIFICAÇÃO DOS BENEFÍCIOS FISCAIS DE ICMS PARA FINS DE GASTO TRIBUTÁRIO}

Os benefícios informados nas normas legais citadas não comportam uma lista exaustiva, como se depreende dos tipos abertos utilizados. Assim, para fins de análise de gasto tributário relativo ao ICMS, compete à doutrina propor uma classificação desses benefícios ${ }^{5}$ e, em seguida, analisar os mais relevantes de forma detalhada ${ }^{6}$, tarefas que objetivamos realizar no presente trabalho.

Inicialmente, para estabelecer a classificação, devemos partir de algumas premissas:

1 - As limitações do poder de tributar, previstas na Constituição Federal ou em Lei Complementar Nacional, não devem ser consideradas como gasto tributário imputável ao Estado, mas a característica inerente à estrutura básica do imposto;

2 - Os benefícios que alteram a norma tributária padrão, notadamente, a incidência, alíquota, base de cálculo, créditos tributários, são alocados na família denominada benefícios tributários;

\footnotetext{
$5 \quad$ O Apêndice I contém exemplos de normas legais que veiculam diversas espécies de benefícios relativas ao ICMS, e o Apêndice II contém exemplos de como pode ser calculado o gasto tributário em cada caso.

$6 \quad \mathrm{O} \S 4^{\circ}$ da Cláusula Primeira do Convênio ICMS 190, de 2017, apresenta uma relação de benefícios fiscais, mas tal como as demais normas citadas, parece não ser exaustiva. Essa relação não contém, por exemplo, a situação de alíquota interna inferior à alíquota interestadual.
} 
3 - Os benefícios, que resultem em redução ou eliminação do ônus tributário ao longo do canal de distribuição, mas não se classificam como benefícios tributários, devem ser alocados na família denominada benefícios fiscais financeiros;

4 - As regras e os tratamentos tributários, que resultem em redução ou eliminação do respectivo ônus a determinado sujeito passivo, mas transferem esse ônus para outro agente ao longo do canal de distribuição, não serão considerados como gastos fiscais, se a cobrança no segundo agente for viável, integral e eficaz.

Classificação dos benefícios em famílias, em função do tipo de norma utilizada.

A - Benefícios Tributários: isenção, redução de base de cálculo, alíquotas diversificadas, crédito outorgado (presumido), não incidência não prevista na legislação nacional são gêneros dessa família, sendo que vários destes se dividem em espécies distintas, por exemplo, a isenção, com ou sem manutenção, dos créditos relativos à entrada;

B - Benefícios fiscais financeiros: anistia, remissão, devolução parcial ou total do tributo pago, parcelamento incentivado, subsídio fiscal ou financeiro, outros incentivos fiscais ou financeiros fiscais são gêneros desta família, sendo que alguns destes comportam mais de uma espécie.

\section{BENEFÍCIOS TRIBUTÁRIOS}

\subsection{A isenção como gênero e suas espécies}

A isenção talvez seja a rainha dos benefícios tributários. É o gênero de benefício tributário mais citado nos textos legais e, consequentemente, na doutrina e na jurisprudência. Ao dispensar o sujeito passivo de pagar o imposto que seria devido, a isenção é um tipo clássico de benefício de natureza tributária. 
No ICMS, por ser tributo não cumulativo, devemos considerar o efeito da isenção sobre os créditos relativos às operações anteriores e também sobre o crédito nas operações posteriores. Considerando conjuntamente esses dois efeitos, teremos que, para fins de gasto tributário, a isenção no ICMS é um gênero que contém pelo menos quatro espécies:

I.1.1 - Isenção sem manutenção de créditos, em operação ou prestação destinada a não contribuinte do ICMS (isenção básica);

I.1.2 - Isenção com manutenção de créditos, em operação ou prestação destinada a não contribuinte do ICMS (isenção ampliada);

I.2.1 - Isenção sem manutenção de créditos, em operação ou prestação destinada ao contribuinte ${ }^{7}$ do ICMS (pseudobenefício);

I.2.2 - Isenção com manutenção de créditos, em operação ou prestação destinada ao contribuinte do ICMS (isenção diferimento).

A isenção básica, por assim dizer, seria a espécie I.1.1, ou seja, a isenção sem manutenção de créditos, em operação destinada a não contribuinte do $\mathrm{ICMS}^{8}$. Nesse tipo de isenção, a renúncia tributária, ou seja, o gasto tributário do ente tributante, é equivalente ao valor do imposto que seria recolhido pelo sujeito passivo, caso sua operação de saída fosse tributada pelo ICMS e o valor dos créditos relativos às operações anteriores fosse utilizado para compensar parte do débito. O montante que deveria ser recolhido na ausência de isenção, resultante da diferença entre débitos das saídas e dos créditos das entradas, é o valor do benefício para o sujeito passivo, sendo também o valor do gasto tributário para o sujeito ativo.

A isenção ampliada seria a espécie I.1.2, ou seja, a isenção com manutenção de créditos relativos às operações anteriores, em operação destinada a não contribuinte do imposto. Nesse caso, o valor do benefício fiscal concedido ao sujeito passivo é a soma do valor do ICMS que ele iria recolher, caso sua operação própria fosse tributada mais o valor relativo

\footnotetext{
$7 \quad$ As referências ao contribuinte do ICMS neste texto se referem aos contribuintes do ICMS sujeitos ao regime geral do imposto, previsto na LC 87, de 1996, que não sejam optantes pelo regime especial de tributação do Simples Nacional e nem a qualquer outro regime especial de tributação.

8 Vide Constituição Federal, art. 155, § 2 , II, "a" e "b".
} 
ao imposto das operações anteriores registrado como crédito. $\mathrm{O}$ benefício seria o benefício I.1.1 acrescido do valor dos créditos registrados e, nesses termos, seria uma isenção ampliada.

A isenção I.2.1, sem manutenção de crédito em operação destinada ao contribuinte do ICMS, se concedida de forma isolada, ou seja, sem se estender até o final do canal de distribuição, pode ser, na realidade, um ganho tributário para o sujeito ativo, configurando um pseudobenefício, e não um gasto tributário.

Explicamos: como se trata de uma isenção de ICMS, no elo intermediário da cadeia de distribuição, que não permite que o valor dos créditos das operações anteriores seja mantido, e considerando que as operações seguintes serão tributadas, sem direito ao valor dos créditos de ICMS relativos às operações anteriores, o valor de ICMS coletado ao longo do canal de distribuição, desde o fabricante ou importador até o consumidor final, será maior do que se não existisse a isenção.

Assim, o benefício tributário concedido ao sujeito passivo não é equivalente a um gasto tributário para o ente tributante, pois o primeiro agente econômico não isento no canal de distribuição irá receber o produto isento, sem crédito de ICMS, e na saída deverá pagar o ICMS da saída sem direito a compensar os créditos da entrada. Como se trata de isenção sem manutenção de crédito, com tributação normal nas operações seguintes, o valor dos créditos não admitidos equivale a um ganho de tributação ao entre tributante. Por isso, essa espécie de benefício tributário não deve ser vista como um gasto tributário, mas como um ganho tributário.

Por outro lado, se a isenção I.2.1 for concedida a todos os elos do canal de distribuição e combinada com uma isenção I.1.1 na saída final a não contribuinte, formando uma sequência de isenções, no que se refere ao gasto tributário o resultado final será a soma do gasto da I.1.1 com o valor de todos os créditos não permitidos aos sujeitos passivos beneficiados com as isenções I.2.1. Isso seria maior que a I.1.1 isolada, mas inferior à isenção I.1.2. 
A isenção I.2.2, com manutenção de crédito em operação destinada ao contribuinte do ICMS, se concedida de forma isolada, no meio do canal de distribuição, sem que as operações seguintes tenham qualquer benefício ou tratamento tributário especial, é um benefício tributário que não gera gasto nem ganho tributário para o ente tributante.

Seria equivalente a uma alteração do dever de pagar o imposto do sujeito passivo favorecido pelo benefício para o sujeito passivo da operação seguinte (não favorecido). Como o sujeito passivo favorecido poderá manter os créditos das operações anteriores e realizar a sua operação própria sem pagar o ICMS, significa que o elo seguinte do canal de distribuição vai receber o produto sem crédito (operação não tributada) e realizar a operação de saída com débito de ICMS (operação tributada). Dessa forma, do ponto de vista do ente tributante, não ocorre um gasto tributário, mas uma alteração da obrigação de pagar de um sujeito passivo a outro, que na linguagem do ICMS tem sido denominada de diferimento. Assim, a isenção da espécie I.2.2 deve ser tratada para fins de gasto tributário, como se fosse um diferimento de ICMS.

\subsection{A redução da base de cálculo e suas espécies}

Por construção doutrinária e jurisprudencial ${ }^{9}$, o benefício tributário de redução de base de cálculo do ICMS tem sido tratado como uma isenção parcial.

Dessa forma, temos quatro espécies de redução de base de cálculo, que são análogas às espécies de isenção: R.1.1, R.1.2, R.2.1 e R.2.2. Nesses casos, o gasto tributário ou ganho tributário, no caso R.2.1, será maior ou menor a depender de quão significativa for a redução da base de cálculo concedida.

9 STF em Repercussão Geral. Tema 299. RE 635688 julgado em 16/10/2014. A redução da base de cálculo de ICMS equivale à isenção parcial, o que acarreta a anulação proporcional de crédito relativo às operações anteriores, salvo disposição em lei estadual em sentido contrário. Redação da tese aprovada nos termos do item 2 , da

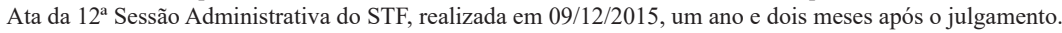


Uma situação peculiar ocorre com reduções de base de cálculo, cuja redação do dispositivo legal segue o modelo: "[...] fica reduzida a base de cálculo de forma que a carga tributária seja equivalente a $\mathrm{x} \%[\ldots]$ " e que cumulativamente: (1) permita a manutenção dos créditos relativos às operações anteriores e (2) seja aplicável sucessivamente a todas as operações até a saída a não contribuinte. Nesse caso, temos uma quinta espécie de redução de base de cálculo, R.3, que para fins de gasto tributário é equivalente a aplicar a alíquota de $\mathrm{x} \%$ de ICMS na operação. Seria a redução de base de cálculo-alíquota.

Outra situação peculiar que pode ocorrer no ICMS é a utilização da base de cálculo do ICMS por Substituição Tributária ${ }^{10}$, por pauta ou por pagamento antecipado terminativo, em valor inferior ao que seria compatível com o valor corrente da mercadoria ou do serviço no mercado ou inferior ao previsto na legislação nacional ${ }^{11}$. Tal redução de base de cálculo atípica, pois disfarçada, configuraria a sexta espécie de redução de base de cálculo, denominada R.4 ou redução de base de cálculo - base subestimada.

No caso R.4, o valor do gasto tributário seria a diferença entre o imposto devido com a utilização da base de cálculo defasada e o valor do imposto que seria devido, caso a base de cálculo tivesse sido fixada na forma prevista na Lei Complementar vigente.

\subsection{A alíquota do ICMS}

A premissa adotada de que devemos considerar gasto tributário como o desvio em relação à estrutura básica do tributo, instituído pela legislação estadual, apresenta como um de seus corolários que se o Estado criar uma alíquota inferior à prevista na estrutura básica da legislação

\footnotetext{
$10 \quad$ Vide LC 87, de 1996, artigo 8, inciso II, “c", c/c $\S \S 4^{\circ}$ e $6^{\circ}$.

11 As regras nacionais para fixação da base de cálculo para fins de substituição tributária estão previstas no artigo $8^{\circ}$, da Lei Complementar 87 de 1996, e regras para arbitrar a base de cálculo são previstas no artigo 18 da mesma lei.
} 
nacional do imposto, tal alíquota reduzida deve ser tratada como um gasto tributário.

A legislação nacional do imposto prevê que: (1) é facultado ao Senado Federal estabelecer alíquotas mínimas de ICMS para as operações internas, o que não ocorreu; (2) as alíquotas internas não poderão ser inferiores às previstas para as operações interestaduais, exceto nos casos permitidos, mediante convênio entre os Estados ${ }^{12}$.

Como o referido convênio entre os Estados é o destinado a aprovar benefícios fiscais relativos ao ICMS, podemos entender que a adoção de qualquer alíquota interna inferior à aplicável nas operações interestaduais configura desvio em relação à estrutura básica do imposto e, portanto, configura um gasto tributário.

O Senado fixou quatro alíquotas de ICMS para operações e prestações interestaduais mediante as Resoluções 22/1989 (7\% e 12\%), 95/1996 (4\% no transporte interestadual de carga) e 13/2012 (4\% para os produtos importados, salvo as exceções). Destas quatro alíquotas, a única de aplicação geral é a de $12 \%$, prevista no artigo $1^{\circ}$ da Resolução $22 / 1989^{13}$, pois as demais tratam de situações específicas, de exceções e não da estrutura básica do imposto.

Dessa forma, entendemos ${ }^{14}$ que qualquer alíquota de ICMS inferior a $12 \%$, aplicável às operações internas em decorrência de legislação estadual, deve ser considerada um gasto tributário de ICMS.

Tal raciocínio também pode ser estendido para a redução de base de cálculo da espécie R.3 e, para qualquer outra norma tributária atípica que, aplicada às operações de determinado sujeito passivo, resulte em uma carga tributária inferior a $12 \%$ do valor das operações de saída, sendo permitida a manutenção dos créditos das entradas.

\footnotetext{
12 Vide Constituição Federal, artigo $155, \S 2^{\circ}$, V e VI.

13 A alíquota do Imposto sobre Operações Relativas à Circulação de Mercadorias e sobre Prestação de Serviços de Transporte Interestadual e Intermunicipal e de Comunicação, nas operações e prestações interestaduais, será de $12 \%$. Artigo $1^{\circ}$, da Resolução do Senado n ${ }^{\circ} 22$, de 1989.

14 O STF se manifestou nesse sentido ao conceder medida cautelar na ADI-MC 2021.
} 


\subsection{Crédito outorgado ou presumido}

As expressões "crédito outorgado" e "crédito presumido" têm sido utilizadas na legislação tributária do ICMS, ora como sinônimas, ora para indicar fenômenos distintos, porém, semelhantes. Não cabe no escopo deste artigo discutir o conceito de cada uma dessas expressões, nem propor a distinção entre uma e outra. Para fins de gasto tributário, podemos distinguir três espécies de crédito outorgado ou presumido de ICMS.

O primeiro caso, C.1, é um crédito bônus. O ente tributante permite que o sujeito passivo se credite de determinado valor, fixo ou variável, a título de crédito de ICMS, mantendo inalterados os créditos ordinários referentes às entradas e os débitos referentes às operações de saída realizadas. Nesse caso, o valor do crédito permitido é o exato valor do gasto tributário realizado.

O segundo caso, C.2, é um crédito troca. O ente tributante permite que o sujeito passivo se credite de determinado valor, fixo ou variável, a título de crédito de ICMS, desde que o sujeito passivo deixe de se creditar de determinados créditos que teria direito face à legislação normal do imposto, em decorrência das entradas ocorridas. Nesse caso, o gasto tributário é o resultado da diferença entre: (1) o valor do crédito permitido em função do benefício tributário e (2) o valor do crédito que o sujeito passivo deixou de utilizar, relativo às entradas ocorridas.

O terceiro caso, C.3, é um crédito conta de chegada. O ente tributante permite que o sujeito passivo se credite de determinado valor a título de crédito de ICMS, no montante necessário e suficiente para que o ICMS apurado no período, que deverá ser recolhido, seja um valor preestabelecido. O crédito é calculado ao final do período (ex-post), para que o ICMS apurado chegue ao valor preestabelecido. Assim, é uma conta de chegada. Em curta síntese, nesse caso, deixa de ser aplicado o modelo "normal" de apuração do ICMS, com débitos pela saída e créditos pela entrada, e 
passa a ser utilizado um modelo distinto, no qual o valor do ICMS a ser recolhido é previamente fixado, com base em uma referência não prevista na legislação nacional do ICMS. Por vezes, adota-se como referência um percentual do valor das saídas totais, um percentual do valor de determinadas saídas ou um valor fixo em reais. Nessa espécie de crédito outorgado, o valor do gasto tributário é a diferença entre o valor do ICMS que seria apurado com as regras normais (com as regras gerais do imposto) e o valor do ICMS apurado em função do benefício tributário concedido.

O crédito outorgado, nas modalidades C.2 e C.3, pode ser utilizado para simplificar o cálculo do imposto devido pelo sujeito passivo, reduzindo custos de apuração e conformidade do lado do sujeito passivo, e custos de fiscalização e auditoria do lado da administração tributária. Mas, se existir diferença entre o valor que seria devido pelas regras gerais do imposto e o valor devido com a aplicação das regras especiais, ocorre o gasto tributário.

\subsection{Não incidência e não exercício da competência tributária}

Na doutrina tributária, a não incidência é o fenômeno que ocorre quando determinado fato do mundo fenomênico não se configura um fato gerador do imposto. Alguns casos de não incidência estão expressamente previstos na Constituição Federal, como a exportação de mercadorias para o exterior. Nesse caso, não advém um gasto tributário, pois se trata da estrutura básica do tributo.

Todavia, existem casos de não incidência tributária que decorrem do não exercício da competência tributária pelo ente tributante. Isso ocorre quando a Constituição Federal atribui a competência normativa ao Estado, a Lei Complementar Nacional descreve o fato como passível de incidência de ICMS, mas a legislação estadual não prevê a incidência ou expressamente afasta a incidência em relação ao fato específico. Nesses casos, temos a não incidência por omissão (NI.1) e a não incidência expressa (NI.2). 
É importante distinguir a não incidência expressa, decorrente apenas de norma estadual, da não incidência didática prevista em norma nacional e repetida na norma estadual para fins didáticos. Enquanto a primeira é um gasto tributário, a segunda não é, pois se trata da estrutura básica do imposto.

O valor do gasto tributário, tanto na hipótese de não incidência por omissão (NI.1), como na hipótese de não incidência expressa (NI.2), deve ser calculado pela diferença entre o valor dos créditos que o sujeito passivo teria direito e o valor dos débitos que seriam devidos, caso a não incidência não existisse.

\subsection{Diferimento, suspensão e casos correlatos}

Existem situações nas quais o sujeito passivo, que pratica o fato gerador e seria o contribuinte natural do imposto, é dispensado de declarar e pagar o ICMS, e outro sujeito passivo, na qualidade de responsável, passa a ter o dever de declarar e pagar o ICMS. Esse tipo de situação geralmente é denominado diferimento, classificado do ponto de vista tributário como uma espécie de substituição tributária e, em regra, não representa um gasto tributário. Isso ocorre, porque o valor do imposto que deixou de ser declarado e pago pelo contribuinte é declarado e pago pelo responsável na operação seguinte ou na seguinte da seguinte.

Todavia, em alguns casos, a legislação é desenhada de tal forma que o imposto diferido nunca é declarado e pago pelo responsável, pois não se cria norma com essa obrigação que abarque todos os casos em que ocorreu o diferimento. Nesse caso, temos o diferimento isenção, que, para fins de gasto tributário, opera de forma análoga à isenção com manutenção de crédito. No diferimento isenção, D.1, o gasto tributário é equivalente ao débito que deixou de ser declarado. 
Outra situação, encontrada no ICMS, é permitir que o sujeito passivo deixe de declarar e pagar o imposto em determinado momento, desde que o faça em momento posterior, quando ocorrer determinado fato. Durante esse intervalo de tempo o imposto fica suspenso. Se, para cada hipótese de suspensão, existir a respectiva hipótese de declaração e pagamento posterior, essa situação não configura um gasto tributário.

Mas, de forma análoga ao que ocorre no diferimento, na suspensão pode ocorrer de a legislação estar desenhada de tal forma que a declaração e o pagamento do imposto no momento posterior não estejam previstos. Nesse caso, teríamos a suspensão isenção, S.1, a qual, do ponto de vista do gasto tributário, equivale a uma isenção com manutenção de crédito de ICMS.

\section{BENEFÍCIOS FISCAIS FINANCEIROS}

\subsection{Anistia e remissão}

Anistia e remissão ${ }^{15}$ são, respectivamente, a dispensa do pagamento da multa e a dispensa do pagamento do imposto devido. Tais favores fiscais podem ser aplicáveis antes ou depois de o débito tributário estar formalmente constituído, a depender do texto da norma legal que os concedeu, e podem significar a dispensa parcial ou integral do débito.

Entendemos que os valores de cuja cobrança for dispensada em decorrência de anistia, A.1, remissão, R.1, e anistia com remissão, AR.1, devem ser tratados, em regra, como gasto tributário.

15 Embora se possa alegar que a anistia não trata de imposto, mas de multa, e não deve ser tratada como um gasto tributário, cabe destacar que o artigo 14, da LC 101/2000, prevê que a anistia é uma renúncia fiscal. Dessa forma, entendemos adequado classificar a anistia como um gasto tributário. LC 101, de 2000, LRF, artigo 14, § $1^{\circ}$, "a renúncia compreende anistia, remissão, subsídio, crédito presumido, concessão de isenção em caráter não geral, alteração de alíquota ou modificação de base de cálculo que implique redução discriminada de tributos ou contribuições, e outros benefícios que correspondam a tratamento diferenciado". Vide, ainda, o Convênio ICMS 126, de 29 de dezembro de 2017. 
Entendemos, ainda, que deve ser computado como gasto tributário o valor dos acréscimos legais, que seriam aplicáveis ao imposto e à multa devidos, tais como juros e atualização monetária, mas que deixaram de ser cobrados em função da anistia ou remissão concedidos.

Todavia, algumas hipóteses específicas de anistia e remissão não deveriam ser tratadas como gasto tributário, pois representam uma gestão eficiente da administração tributária, uma redução líquida de gastos públicos, e não um gasto. Um exemplo desse tipo de anistia e remissão, que não deve ser classificado como gasto tributário, seria a anistia e remissão de débitos de pequeno valor, cuja cobrança envolveria um gasto maior do que o valor que se pretende receber.

\subsection{Parcelamento e parcelamento incentivado}

O parcelamento de débito tributário afeta a receita tributária do exercício, pois se deixa de receber o valor no próprio exercício, à vista, para receber em exercícios seguintes. Assim, em regra, o parcelamento é uma causa de gasto tributário. No entanto, em determinadas situações, o parcelamento talvez não deva ser considerado um gasto tributário, mas uma ferramenta de cobrança administrativa ou judicial do débito tributário que deixou de ser pago tempestivamente. Nessa hipótese, o parcelamento seria uma ferramenta de gestão da administração tributária.

Entendemos que o parcelamento não deveria ser considerado um gasto tributário, se três condições forem atendidas: (1) o valor parcelado deve ter como origem ICMS devido, não pago tempestivamente, acrescido de multa, juros e correção monetária; (2) o valor a ser pago no futuro, trazido a valor presente pela taxa Selic, deve igual ou superior ao valor do débito para pagamento à vista; (3) o parcelamento deve ser concedido apenas para situações específicas e determinadas, deve ter limites, não podendo ser utilizado como regra ordinária de pagamento do imposto. 
A violação da restrição (1) significa que o parcelamento é, na realidade, o prazo ordinário de pagamento do imposto, e não uma forma de pagar o imposto já vencido, líquido e exigível ${ }^{16}$. Se for esse o caso, temos um parcelamento prazo ordinário extralongo, P.1.

A violação da restrição (2) significa que o parcelamento é combinado com um benefício fiscal, pois o valor presente das parcelas vincendas, descontado à taxa de juros Selic, será inferior ao valor do débito tributário parcelado ${ }^{17}$. Essa situação configura um parcelamento financeiramente beneficiado, P.2.

A violação da restrição (3) significa que o contribuinte poderá sempre deixar de recolher o valor do imposto devido e parcelar o valor devido ao longo do tempo, sem quaisquer limites e condições, de forma continu$\mathrm{ada}^{18}$. Tal situação deve ser tratada como um gasto tributário e configura um parcelamento generalizado, P.3.

É comum observar o parcelamento combinado com anistia (total ou parcial), remissão parcial e juros reduzidos. Esse caso de gasto tributário, decorrente do combo de benefícios fiscais e tributários, deve ser tratado como parcelamento incentivado, P.4.

Destacamos que se os prazos ordinários de recolhimento do ICMS forem posteriores ao (1) décimo dia do segundo mês subsequente àquele em que tenha ocorrido o fato gerador, para indústrias, ou ao (2) vigésimo dia do mês subsequente, para os demais contribuintes, tais prazos devem ser tratados como benefício fiscal. Nesse caso, teríamos o gasto tributário da espécie parcelamento prazo, P.5.

Nos casos de gasto tributário decorrente de parcelamento, o valor do gasto tributário deve ser calculado pela diferença entre o valor do débito tributário para pagamento à vista, na data do vencimento, sem quaisquer

16 Vide Cláusula Sexta do Convênio ICMS 126, de 29 de dezembro de 2017, que trata do prazo de pagamento do ICMS.

17 Vide CTN, artigos 155, 155-A, e 161, e Cláusula Décima Segunda do Convênio ICMS 126, de 29 de dezembro de 2017, que trata de atualização dos valores devidos de ICMS.

18 Vide Convênio ICMS 126, de 29 de setembro de 2017, que estabelece as condições nas quais os Estados podem conceder parcelamento. 
descontos de juros, multa e impostos devidos, e o valor presente líquido das parcelas vincendas descontado à taxa Selic.

\subsection{Devolução total ou parcial}

Nesse gênero de benefício fiscal financeiro, o valor do ICMS incidente na operação é determinado com a utilização de alíquota e base de cálculo normais, isto é, compatíveis com as regras ordinárias do ICMS, e o imposto é apurado e recolhido sem nenhum benefício tributário. Todavia, após o recolhimento do valor devido, o ente tributante, de forma direta ou indireta, realiza a devolução parcial ou total do valor do imposto pago.

$\mathrm{O}$ exemplo clássico desse gênero de benéfico fiscal financeiro é o Fundap, instituído na década de 1970. No Fundap, após o imposto ser recolhido para o Estado, o banco interveniente faz a liberação do dinheiro para o contribuinte, a título de financiamento, retém um percentual, e o saldo devedor do financiamento pode ser liquidado antecipadamente em leilão em condições financeiras vantajosas ${ }^{19}$.

Existem diversas formas de se desenhar esse tipo de benefício, com diferentes graus de criatividade e complexidade. Nesses casos, como regra geral, o montante do gasto tributário é o valor presente líquido da "devolução" recebida, que pode assumir formas jurídicas e econômicas mais diversas.

\subsection{Subsídio fiscal ou financeiro}

Na teoria da tributação, é possível encontrar definições que distingam incentivos fiscais, conceituados como a redução ou exclusão da carga tributária, de subsídios fiscais, conceituados como vantagens financeiras

\footnotetext{
19 O Fundap é um financiamento para apoio a empresas com sede no Espírito Santo e que realizam operações de comércio exterior tributadas com ICMS no Estado. Empresas industriais com sede no Espírito Santo, que fazem uso de insumo importado, também podem se habilitar aos financiamentos do Fundap. Vide Manual Operacional do Fundap em: https://bit.ly/3mTEHQ7.
} 
dadas pelo governo para alcançar algum resultado, mas cuja natureza não seja relacionada, ainda que indiretamente, à devolução ou ao reembolso da carga tributária decorrente da atividade do contribuinte ${ }^{20}$.

No âmbito do ICMS, o benefício fiscal do gênero subsídio seria definido como uma vantagem financeira concedida pelo Estado tributante ao contribuinte, desde que observadas certas condições que não sejam relacionadas, direta ou indiretamente, ao ICMS pago ou devido, em função da atividade realizada pelo sujeito passivo.

Seria, por exemplo, a concessão de um valor à empresa, digamos, 10 mil reais por mês, durante determinado prazo, digamos 60 meses, condicionado à ocorrência de determinado evento, digamos a manutenção de 20 funcionários no estabelecimento, e limitado ao valor do ICMS recolhido no mês anterior.

É necessário que exista alguma ligação entre o valor do subsídio e o ICMS, passado, presente ou futuro, ainda que seja relativa ao cálculo do montante, para que o benefício fiscal possa ser considerado um gasto tributário desse imposto. $\mathrm{O}$ valor do gasto tributário é o valor do subsídio concedido.

5.5 Outros incentivos fiscais ou financeiros fiscais, que resultem em redução ou eliminação do ônus tributário ordinário

Esse gênero é de natureza residual. Isso significa que devem ser classificadas nele as espécies de benefícios fiscais ou financeiros relativas ao ICMS, não classificadas nos gêneros anteriores que, de alguma forma, resultem em redução ou eliminação do ônus tributário ordinário.

Em regra, o valor do gasto tributário nos casos de benefício fiscal financeiro puro, ou seja, não combinado com benefício tributário, é a diferença entre o valor do imposto apurado, e o valor líquido dispendido

20 Nesse sentido, veja Dênia Maria Milagres, em "Incentivos Fiscais", v. 29, n. 3, Revista de Ciência Política, p. 105, 1986. 
para pagar o imposto ${ }^{21}$, trazido a valor presente, quando parte do montante pago for a prazo.

$\mathrm{Na}$ hipótese de benefício combinado, de natureza tributária e financeira, a mensuração pode ser realizada em duas etapas. Primeiro, analisando o gasto tributário decorrente do benefício tributário. Depois, analisando o gasto financeiro decorrente do benefício financeiro e, finalmente, somando ambos.

Um caso interessante, nesse tipo residual de benefício, é o regime especial que substitui o cálculo do ICMS devido no método tradicional de débitos pelas saídas menos créditos pelas entradas, pela aplicação de um percentual fixo sobre a saída, sem permitir créditos pelas entradas, o que, na prática, transforma o imposto de não cumulativo em um tributo cumulativo sobre o valor das saídas ou das vendas.

Seria o regime especial de percentual sobre as vendas, RE.1. Nesse caso, o gasto tributário seria a diferença entre o valor pago e o valor que seria devido, aplicando o método tradicional de apuração do imposto.

\section{CONSIDERAÇÕES FINAIS}

Este estudo tem por objetivo identificar, por meio de pesquisa qualitativa, espécies de benefícios fiscais com esse imposto e demonstrar a possibilidade de mensurar o montante de recursos públicos renunciados em cada modalidade identificada.

Verificamos que os benefícios tributários relativos ao ICMS podem ser definidos de diversas formas e concedidos por meio de normas com redação as mais variadas. Mesmo considerando esse obstáculo, conseguimos atingir nosso objetivo de identificar modalidades desses benefícios, assim como métodos de mensuração dos valores renunciados, como demonstramos no texto principal e nos dois apêndices deste artigo.

21 O valor líquido gasto seria a diferença entre o valor bruto gasto, trazido a valor presente, e o valor de eventuais montantes recebidos, também trazidos a valor presente, utilizando a taxa Selic como parâmetro de juro. 
Para fins de cálculo do gasto tributário de ICMS nos Estados, devem ser consideradas apenas as normas estaduais que se distanciam da estrutura básica do imposto. Dessa forma, as regras nacionais, previstas na Constituição Federal e em leis complementares, não podem ser consideradas como fontes de gastos tributários do ICMS nos Estados.

Apenas normas estaduais, que permitem ao sujeito passivo ou ao canal de distribuição pagar um valor menor de ICMS, é que devem ser consideradas como fontes de gasto tributário. Tais normas podem ser relativas aos benefícios tributários, benefícios fiscais financeiros (famílias) ou a ambos conjuntamente e podem ser classificadas em famílias, gêneros e espécies, para facilitar sua identificação e o cálculo do gasto tributário decorrente, como exemplificado nos Apêndices I e II.

O tema é abrangente e complexo. Assim, a classificação e os critérios ora propostos são os primeiros passos no que se refere especificamente à elaboração de uma metodologia destinada à identificação e mensuração do gasto tributário relativo ICMS, que possibilite aos Tribunais de Contas aferir a relação custo benefício de cada modalidade de renúncia fiscal com esse imposto.

Mensurar os valores de ICMS, renunciados por um estado, não pode ser um fim em si mesmo, mas um passo no caminho de verificar se os benefícios deferidos estão sendo eficazes em atingir suas metas - isso quando são estabelecidas metas (GRADVOHL, 2016) - tarefa propícia aos órgãos de controle.

Nesse sentido, resta clara a necessidade de uma atuação conjunta dos tribunais de contas com servidores das Administrações Tributárias expertos em ICMS. Identificar quais dados são importantes, onde se encontram e transformá-los em informações úteis já demonstramos ser factível. Entendemos que o próximo passo deve ser a efetivação dessa união de conhecimentos em um projeto piloto para aferir empiricamente os resultados ora apresentados e realizar os desenvolvimentos necessários. 
As questões tratadas neste artigo podem e devem ser aprimoradas por meio de críticas e aperfeiçoamentos posteriores, pois a construção do conhecimento é uma tarefa coletiva e progressiva.

\section{REFERÊNCIAS}

ALAGOAS. Decreto $n^{\circ}$ 38.317, de 22 de março de 2000. Dispõe sobre o regime de substituição tributária nas operações que destinem mercadorias a revendedores que efetuem venda porta-à-porta. Diário Oficial do Estado de Alagoas, Maceió, 23 mar. 2020. Disponível em: https://bit. ly/3mXw86A. Acesso em: 8 nov. 2020.

ALAGOAS. Lei n ${ }^{0}$ 5.901, de 02 de janeiro de 1997. Altera dispositivos da Lei $n^{\circ} 5.671$, de $1^{\circ}$ de fevereiro de 1995 , que dispõe sobre o programa de desenvolvimento integrado do Estado de Alagoas - PRODESIN. Diário Oficial do Estado de Alagoas, Maceió, 2 jan. 1997. Disponível em: https://bit.ly/39MHJ4V. Acesso em: 8 nov. 2020.

BAHIA. Decreto $n^{0}$ 5.444, de 30 de maio de 1996. Aprova o Regulamento do Imposto sobre Operações Relativas à Circulação de Mercadorias e sobre Prestações de Serviços de Transporte Interestadual e Intermunicipal e de Comunicação (ICMS). Salvador: Governo do Estado, 1996. Disponível em: https://bit.ly/3mVpwpl. Acesso em: 8 nov. 2020.

BAHIA. Decreto $\mathbf{n}^{\mathbf{0}} \mathbf{7 . 7 9 8}$, de 05 de maio de 2000. Aprova o regulamento do fundo de desenvolvimento social e econômico - Fundese, dos programas a ele vinculados e dá outras providências. Salvador: Governo do Estado, 2000. Disponível em: https://bit.ly/3oASNGb. Acesso em: 8 nov. 2020. 
BAHIA. Decreto $\mathbf{n}^{\mathbf{0}} \mathbf{7 . 7 9 9}$, de 09 de maio de 2000. Dispõe sobre o tratamento tributário nas operações que indica e dá outras providências. Salvador: Governo do Estado, 2000. Disponível em: https://bit.ly/31RZSk3. Acesso em: 8 nov. 2020.

BAHIA. Decreto $\mathbf{n}^{\circ} \mathbf{1 9 . 1 9 0}$, de 27 de agosto de 2019. Dispõe sobre o tratamento tributário nas operações realizadas por central de distribuição de lojas de departamento, e dá outras providências. Salvador: Governo do Estado, 2019. Disponível em: https://bit.ly/39Qxahe. Acesso em: 8 nov. 2020.

BRASIL. Convênio ICMS 126, de 29 de setembro de 2017. Brasília, DF: Conselho Nacional de Política Fazendária, 2017. Diário Oficial da União, Brasília, DF, 5 out. 2017. Disponível em: https://bit.ly/39Nnd44. Acesso em: 8 nov. 2020.

BRASIL. [Constituição (1988)]. Constituição da República Federativa do Brasil de 1988. Brasília, DF: Presidência da República, [2020]. Disponível em: https://bit.ly/32O3YmL. Acesso em: 6 nov. 2020.

BRASIL. Lei $n^{0}$ 5.172, de 25 de outubro de 1966. Dispõe sobre o Sistema Tributário Nacional e institui normas gerais de direito tributário aplicáveis à União, Estados e Municípios. Brasília, DF: Presidência da República, [1966]. Disponível em: https://bit.ly/3mVEnQC. Acesso em: 8 nov. 2020.

BRASIL. Lei Complementar $n^{0}$ 87, de 3 de setembro de 1996. Dispõe sobre o imposto dos Estados e do Distrito Federal sobre operações relativas à circulação de mercadorias e sobre prestações de serviços de transporte interestadual e intermunicipal e de comunicação, e dá outras providências. Brasília, DF: Presidência da República, [1996]. Disponível em: https://bit.ly/39RUmvA. Acesso em: 8 nov. 2020. 
BRASIL. Lei Complementar $n^{0}$ 101, de 4 de maio de 2000. Estabelece normas de finanças públicas voltadas para a responsabilidade na gestão fiscal e dá outras providências. Brasília, DF: Presidência da República, [2000]. Disponível em: https://bit.ly/3ovlkNn. Acesso em: 8 nov. 2020.

\section{BRASIL. Resolução do Senado Federal n 22, de 19 de maio de 1989.}

Estabelece alíquota do imposto sobre operações relativas a circulação de mercadorias e sobre prestação de serviços de transporte interestadual e intermunicipal e de comunicação, nas operações e prestações interestaduais. Brasília, DF: Presidência da República, [1989]. Disponível em: https://bit. ly/3ouq5qE. Acesso em: 8 nov. 2020.

BRASIL. Supremo Tribunal Federal. ADI-MC 2021. Relator: Ministro Maurício Corrêa. Brasília, 04 de agosto de 1999. Brasília, DF: Diário da Justiça, [1999].

BRASIL. Supremo Tribunal Federal. Repercussão Geral, Tema 299. RE 635688. Relator: Ministro Gilmar Mendes. Brasília, 16 de outubro de 2014. Brasília, DF: Diário da Justiça Eletrônico, [2014].

CEARÁ. Decreto $n^{\circ} 22.083$, de 10 de setembro de 1992. Dispõe sobre o prazo de recolhimento do ICMS para os estabelecimentos industriais de embalagens flexíveis de polietileno e polipropileno. Diário Oficial do Estado do Ceará, Fortaleza, 10 ago. 1992. Disponível em: https://bit.ly/ 3gqVzuT. Acesso em: 8 nov. 2020.

ESPÍRITO SANTO. Decreto $n^{\circ} 3.174$, de 14 de dezembro de 2012. Regulamenta a Lei $\mathrm{n}^{\circ} 9.937$ de 22 de novembro de 2012. Diário Oficial do Estado do Espírito Santo, Vitória, 22 nov. 2012. Disponível em: https:// bit.ly/2VM8qhM. Acesso em: 8 nov. 2020. 
ESPÍRITO SANTO. Lei no 2.508, de 22 de maio de 1970. Dispõe sobre a autorização para criação do Fundo de Desenvolvimento das Atividades Portuárias - Fundap, e dá outras providências. Diário Oficial do Estado do Espírito Santo, Vitória, 2 jul. 1970. Disponível em: https://bit.ly/ 2JMs5Mf. Acesso em: 8 nov. 2020.

ESPÍRITO SANTO. Lei no ${ }^{\circ}$.937, de 23 de novembro de 2012. Dispõe sobre a legislação de regência do Fundo para o desenvolvimento das Atividades Portuárias - Fundap. Diário Oficial do Estado do Espírito Santo, Vitória, 17 dez. 2012. Disponível em: https://bit.ly/2LiaufB. Acesso em: 8 nov. 2020.

GRADVOHL, M. A. B. L. Necessidade de controle dos benefícios tributários. Revista Controle, Fortaleza, v. 14, n. 2, p. 82-115, 2016.

MILAGRES, D. M. Incentivos fiscais. Revista de Ciência Política, Rio de Janeiro, v. 29, n. 3, p. 103-117, 1986. Disponível em: https://bit. ly/2K0Ri58. Acesso em: 8 nov. 2020.

MINAS GERAIS. Decreto no 47.762 , de 20 de novembro de 2019. Dispõe sobre os procedimentos a serem adotados pelo contribuinte adquirente mineiro ou pelo substituto tributário, inclusive o localizado em outra unidade da Federação, para a remissão de créditos tributários relativos ao ICMS, decorrentes de operações para as quais tenham sido concedidos benefícios em desacordo com o disposto na alínea "g" do inciso XII do $\S 2^{\circ}$ do art. 155 da Constituição Federal, e na Lei Complementar Federal no 24, de 7 de janeiro de 1975. Diário Oficial do Estado de Minas Gerais, Belo Horizonte, 21 nov. 2019. Disponível em: https://bit.ly/2JUcx8R. Acesso em: 8 nov. 2020. 
PARAÍBA. Lei n $^{\circ} 11.707$, de 10 de junho de 2020. Dispõe sobre a remissão e a anistia de créditos tributários, constituídos ou não, na forma que especifica o Convênio ICMS 14/20. Diário Oficial do Estado da Paraíba, João Pessoa, 12 jun. 2020. Disponível em: https://bit.ly/31XLerw. Acesso em: 8 nov. 2020.

PELLEGRINI, J. A. Gastos Tributários: conceitos, experiência internacional e o caso do Brasil. Brasília, DF: núcleo de estudos e Pesquisas, 2014. Disponível em: https://bit.ly/2ImHYYW. Acesso em: 8 nov. 2020.

PERNAMBUCO. Lei Complementar n ${ }^{\circ} 362$, de 22 de junho de 2017. Institui o Programa Especial de Recuperação de Créditos Tributários - PERC, que dispõe sobre a redução parcial de valores de multas e juros previstos na legislação do ICM e do ICMS nas condições que especifica, bem como promove alterações na Lei Complementar no 107, de 14 de abril de 2008. Diário Oficial do Estado do Pernambuco, Recife, 22 jun. 2017. Disponível em: https://bit.ly/3mWkDfL. Acesso em: 8 nov. 2020.

RIO DE JANEIRO (Estado). Decreto n ${ }^{\circ}$ 38.938, de 07 de março de 2006. Altera o tratamento tributário para trigo e os produtos que menciona, e dá outras providências. Diário Oficial do Estado do Rio de Janeiro, Rio de Janeiro, 7 mar. 2006. Disponível em: https://bit.ly/31Uv962. Acesso em: 8 nov. 2020.

RIO DE JANEIRO (Estado). Decreto $n^{\circ} 41.483$, de 18 de setembro de 2008. Dispõe sobre a concessão de tratamento tributário diferenciado para os contribuintes que menciona e dá outras providências. Diário Oficial do Estado do Rio de Janeiro, Rio de Janeiro, 19 set. 2008. Disponível em: https://bit.ly/3mW17CB. Acesso em: 8 nov. 2020. 
RIO DE JANEIRO (Estado). Lei n ${ }^{\circ} 3.578$, de 6 de junho de 2001. Ratifica instrumento firmado pelo Estado do Rio de Janeiro. Diário Oficial do Estado do Rio de Janeiro, Rio de Janeiro, 6 jun. 2001. Disponível em: https://bit.ly/3oydqmE. Acesso em: 8 nov. 2020.

RIO DE JANEIRO (Estado). Lei n ${ }^{\circ}$ 4.189, de 29 de setembro de 2003. Dispõe sobre a concessão de incentivos fiscais às empresas que vierem a investir nas regiões norte-noroeste fluminenses, e dá outras providências. Diário Oficial do Estado do Rio de Janeiro, Rio de Janeiro, 30 dez. 2003. Disponível em: https://bit.ly/36XIwOJ. Acesso em: 8 nov. 2020.

RIO DE JANEIRO (Estado). Lei no 4.531, de 31 de março de 2005. Dispõe sobre a concessão de tratamento tributário especial para os estabelecimentos industriais que especifica com sede localizada no Estado do Rio de Janeiro, e dá outras providências. Diário Oficial do Estado do Rio de Janeiro, Rio de Janeiro, 31 mar. 2005. Disponível em: https://bit.ly/3gtM8ef. Acesso em: 8 nov. 2020.

RIO GRANDE DO SUL. Decreto n ${ }^{\circ}$ 37.699, de 26 de agosto de 1997. Aprova o Regulamento do Imposto sobre Operações Relativas à Circulação de Mercadorias e sobre Prestações de Serviços de Transporte Interestadual e Intermunicipal e de Comunicação (RICMS). Diário Oficial do Estado do Rio Grande do Sul, Porto Alegre, 26 ago. 1997. Disponível em: https://bit.ly/3glm818. Acesso em: 8 nov. 2020.

SANTA CATARINA. Decreto ${ }^{\circ}$ 2.870, de 27 de agosto de 2001. Aprova o Regulamento do Imposto sobre Operações Relativas à Circulação de Mercadorias e sobre Prestações de Serviços de Transporte Interestadual e Intermunicipal e de Comunicação do Estado de Santa Catarina. Diário Oficial do Estado de Santa Catarina, Florianópolis, 28 ago. 2001. Disponível em: https://bit.ly/33Uq2fM. Acesso em: 8 nov. 2020. 
SANTA CATARINA. Lei n⿳ 12.498, de 12 de dezembro de 2002. Altera a Lei $n^{\circ} 10.297$, de 1996, que dispõe sobre o ICMS. Diário Oficial do Estado de Santa Catarina, Florianópolis, 17 dez. 2002. Disponível em: https://bit.ly/2VP2NPV. Acesso em: 8 nov. 2020.

SÃO PAULO (Estado). Decreto no 45.490, de 30 de novembro de 2000. Aprova o Regulamento do Imposto Sobre Operações Relativas à Circulação de Mercadorias e Sobre Prestações de Serviços de Transporte Interestadual e Intermunicipal e de Comunicação - RICMS. Diário Oficial do Estado de São Paulo, São Paulo, 30 nov. 2000. Disponível em: https:// bit.ly/2JXktGz. Acesso em: 8 nov. 2020.

TESOURO NACIONAL. Boletim de finanças dos entes subnacionais. Brasília, DF, 2020. Disponível em: https://bit.ly/3mP40Tc. Acesso em: 8 nov. 2020.

\section{APÊNDICE I}

Exemplos de normas legais que veiculam as espécies de benefício

\section{PARTE A - BENEFÍCIOS TRIBUTÁRIOS}

\section{Isenção}

I.1.1 - Isenção básica - Isenção sem manutenção de créditos, em operação ou prestação destinada a não contribuinte do ICMS.

Exemplo: art. 86, Anexo I, do RICMS/SP: fica isenta a saída ou fornecimento de água natural proveniente de serviços públicos de captação, tratamento e distribuição para redes domiciliares, efetuada por órgão da Administração Pública, centralizada ou descentralizada, inclusive por 
empresa concessionária ou permissionária.

I.1.2 - Isenção ampliada - Isenção com manutenção de créditos, em operação ou prestação destinada a não contribuinte do ICMS.

Exemplo: art. 55, Anexo I, do RICMS/SP: ficam isentas as operações e as prestações de serviços internas, relativas à aquisição de bens, mercadorias ou serviços por órgãos da Administração Pública Estadual Direta e suas Fundações e Autarquias.

I.2.1 - Pseudobenefício - Isenção sem manutenção de créditos, em operação ou prestação destinada ao contribuinte do ICMS.

Exemplo: art. 139, Anexo I, do RICMS/SP: fica isenta a prestação de serviço de transporte intermunicipal rodoviário, ferroviário ou aquaviário de bem ou mercadoria, destinada ao contribuinte do imposto neste Estado, desde que o serviço de transporte tenha início e término em território paulista.

I.2.2 - Isenção/diferimento - Isenção com manutenção de créditos, em operação ou prestação destinada ao contribuinte do ICMS.

Exemplo: art. 24, Anexo I, do RICMS/SP: fica isenta a saída interna de óleo diesel destinado ao consumo por embarcação pesqueira nacional registrada neste Estado na Capitania dos Portos e no Instituto Brasileiro de Meio Ambiente e Recursos Renováveis - Ibama.

\section{Redução da Base de Cálculo}

R.1.1 - Redução básica, sem manutenção de créditos, em operação ou prestação destinada a não contribuinte do ICMS.

Exemplo: art. 268, inciso XVIII, do RICMS/BA: é reduzida a base de cálculo nas operações internas com querosene de aviação (QAV) destinado à empresa de serviço de transporte aéreo de passageiros (transporte aéreo de passageiro está fora do campo de incidência do ICMS).

R.1.2 - Redução ampliada, com manutenção de créditos, em opera- 
ção ou prestação destinada a não contribuinte do ICMS.

Exemplo: art. $1^{\circ}, \S 3^{\circ}$, c/c Art. $3^{\circ}, \S 1^{\circ}$, do Decreto BA 7799, de 2000: nas operações de saídas internas de estabelecimentos inscritos no Cadastro de Contribuintes do ICMS sob os códigos de atividades econômicas constantes do Anexo Único, que integram este Decreto, destinadas à pessoa jurídica não contribuinte do ICMS, a base de cálculo será reduzida, e não será exigido o estorno proporcional dos créditos fiscais relativos aos insumos e bens adquiridos e aos serviços tomados, vinculados às operações subsequentes amparadas pelo benefício previsto neste artigo.

R.2.1 - Redução pseudobenefício, sem manutenção de créditos, em operação ou prestação destinada a contribuinte do ICMS.

Exemplo: art. $3^{\circ}$, do Decreto RJ 41.483, de 2008: fica concedida redução da base de cálculo do ICMS incidente nas operações internas realizadas pelos estabelecimentos atacadistas com produtos de perfumaria, cosméticos e de toucador, relacionados no anexo único a este Decreto, de forma que a carga tributária seja equivalente a 14\% (quatorze por cento), sendo $2 \%$ (dois por cento) destinado ao FECP.

R.2.2 - Redução diferimento, com manutenção de créditos, em operação ou prestação destinada a contribuinte do ICMS.

Exemplo: art. 90, do RICMS/SC: fica reduzida a base de cálculo do imposto nas operações promovidas por distribuidores ou atacadistas estabelecidos em território catarinense com destino ao contribuinte do imposto, em 29,411\%, nas saídas de mercadorias sujeitas à alíquota de 17\% (dezessete por cento).

R.3 - Redução de base de cálculo/alíquota. É a redução de base de cálculo que, para fins de gasto tributário, equivale a aplicar uma alíquota de $\mathrm{x} \%$ de ICMS na operação.

Exemplo: art. $1^{\circ}$, Anexo II, do RICMS/SP: fica reduzida a base de cálculo do imposto incidente em operação, interna ou interestadual, com os produtos a seguir indicados de forma que a carga tributária resulte no 
percentual de $4 \%$ (quatro por cento).

Exemplo: art. 47, RICMS/RJ: a base de cálculo do ICMS na saída interna de gás liquefeito de petróleo (GLP), de gás liquefeito derivado de gás natural (GLGN) e de gás natural é reduzida de forma que a carga tributária incidente resulte no percentual de 12\% (doze por cento).

R.4 - Redução de base de cálculo/base subestimada. É a utilização da base de cálculo com o valor corrente da mercadoria, do serviço no mercado ou inferior ao previsto na legislação nacional.

Exemplo: art. 50, do RICMS/SP: em operação realizada com programa para computador (software), personalizado ou não, o imposto será calculado sobre uma base de cálculo que corresponderá ao dobro do valor de mercado do seu suporte informático.

Exemplo: art. $2^{\circ}, \S 1^{\circ}$, do Decreto AL 38.317, de 2000: fixa margem de valor agregado (MVA) diferenciado para contribuinte com regime especial de venda porta à porta.

\section{Alíquota}

A.1 - Alíquota interna inferior a $12 \%$ (doze por cento). Exemplo: art. 26, do RICMS/SC:

As alíquotas do imposto, nas operações e prestações internas, inclusive na entrada de mercadoria importada e nos casos de serviços iniciados ou prestados no exterior, são: [...] IV - 7\% (sete por cento) nas prestações de serviços de comunicação destinadas a empreendimentos enquadrados no Programa de Fomento às Empresas Prestadoras de Serviço de 'Telemarketing'.

\section{Crédito outorgado ou presumido}

C.1 - Crédito bônus.

Exemplo: art. 15, XIX, “a”, do RICMS/SC: fica concedido crédi- 
to presumido ao fabricante estabelecido neste Estado, equivalente a 5\% (cinco por cento) do valor das saídas internas dos seguintes produtos: café torrado em grão ou moído.

Exemplo: art. 1º do Decreto BA 19190, de 2019: nas operações realizadas por central de distribuição de lojas de departamento será concedido crédito presumido equivalente a 1,5\% (um inteiro e cinco décimos por cento) do valor total das entradas interestaduais de mercadorias tributadas com alíquota de $7 \%$ (sete por cento), limitado o referido valor a 3\% (três por cento) do valor total das operações de saídas interestaduais de mercadorias tributadas realizadas no respectivo período fiscal de apuração.

C.2 - Crédito troca.

Exemplo: Art. 15, X, do RICMS/SC: fica concedido crédito presumido ao fabricante estabelecido neste Estado, de 4\% (quatro por cento), calculado sobre o valor da entrada de leite in natura produzido em território catarinense, proporcionalmente às saídas tributadas de produtos derivados de leite, observado que o benefício será utilizado em substituição aos créditos referidos no art. 41 do Regulamento.

Exemplo: art. 52, do RICMS/SC: em substituição aos créditos efetivos do imposto, observado o disposto no art. 23, o contribuinte poderá optar por crédito presumido de $33,33 \%$ do valor do imposto devido na prestação interna de serviço de transporte aéreo.

C.3 - Crédito conta de chegada.

Exemplo: art. 15, XIII, “a”, do RICMS/SC: fica concedido crédito presumido ao fabricante estabelecido neste Estado, vedada a utilização de qualquer outro benefício fiscal previsto neste Regulamento, nas saídas de farinha de trigo e mistura para a preparação de pães classificadas no código 1901.20.9900 da NBM/SH, calculadas sobre o valor do imposto devido pela operação própria, no percentual de $100 \%$ (cem por cento), quando o destinatário for contribuinte localizado no Estado de São Paulo.

Exemplo: art. $2^{\circ}$, da Lei RJ 4189, de 2003: concessão de crédito presumido de até $100 \%$ (cem por cento) do ICMS. 


\section{Não incidência}

NI.1 Não incidência por omissão.

Exemplo. Lei SC 12.498, de 2002, no que se refere à incidência de ICMS na importação realizada por não contribuinte do ICMS. O STF, no julgamento do RE $n^{\circ}$ 439.796, entendeu que:

Para que a constituição do crédito tributário seja válida, a incidência deve ocorrer na presença concomitante dessas três condicionantes: existência de competência, exercício dessa competência pela União, resultante em norma geral em matéria tributária e exercício de competência por cada um dos estadosmembros e pelo Distrito Federal.

Razão pela qual, para serem consideradas válidas, as leis estaduais deveriam ter sido editadas posteriormente à EC 33/2001 e à LC 114/2002. Assim, no julgamento do RE $\mathrm{n}^{0} 744.694$, reconheceu a inconstitucionalidade da Lei do Estado de Santa Catarina (Lei n ${ }^{\circ} 12.498 / 02$ ), e a não incidência de ICMS nas importações dessa natureza, até que fosse publicada lei para instituir no imposto para esta situação.

NI.2 Não incidência expressa.

Exemplo: art. $7^{\circ}, \mathrm{XVII}$, do RICMS/SP. Prevê a não incidência do ICMS no desembaraço aduaneiro decorrente de reimportação de bem ou mercadoria remetido ao exterior sob amparo do Regime Aduaneiro Especial de Exportação Temporária.

\section{Diferimento}

D.1 - A legislação é desenhada de tal forma que o imposto diferido nunca é declarado e pago pelo responsável, pois não se cria norma com essa obrigação que abarque todos os casos em que ocorreu o diferimento.

Exemplo: art. 54, II, "a", do Livro I, do RICMS/RS: exclui-se a 
responsabilidade pelo pagamento do imposto diferido: relativamente às entradas decorrentes de importação do exterior das mercadorias referidas: no Apêndice XVII, itens [...] Trata da exclusão de responsabilidade pelo pagamento do imposto diferido relativamente às entradas decorrentes de importação de partes, peças e componentes para a fabricação de vagões e locomotivas.

Exemplo: art. $4^{\circ}$, do Decreto RJ 38.938, de 2006: fica dispensado o pagamento do imposto diferido referente às operações anteriores à venda ao consumidor final dos seguintes produtos mencionados no Decreto $\mathrm{n}^{\mathrm{o}}$ 32.161, de 11 de novembro de 2002 [...].

\section{Suspensão}

S.1 - A legislação está desenhada de tal forma que a declaração e pagamento do imposto no momento posterior não esteja prevista ou, na prática, não se aplique às situações fáticas ocorridas.

Exemplo: art. 400-N, do RICMS/SP: o lançamento do imposto incidente no desembaraço aduaneiro de mercadoria, sem similar produzida no país, destinada à sociedade de propósito específico, localizada neste Estado, para posterior fornecimento como matéria-prima ou produto intermediário na fabricação de medicamento pela Fundação para o Remédio Popular (Furp), quando a importação for efetuada diretamente pela referida sociedade, fica suspenso para o momento em que esta promover a saída da mercadoria de seu estabelecimento.

\section{Parte B - Benefícios fiscais financeiros}

\section{Anistia e remissão}

\section{A.1 - Anistia.}

Exemplo: art. $2^{\circ}$, inciso I, da LC PE 362, de 2017: redução do cré- 
dito tributário corresponde aos seguintes percentuais, na hipótese de pagamento à vista, $85 \%$ (oitenta e cinco por cento) da multa e $90 \%$ (noventa por cento) dos juros.

R.1 - Remissão.

Exemplo: art. $1^{\circ}$ do Decreto MG 47.762, de 2019. Para a remissão de créditos tributários, relativos ao ICMS, decorrentes de operações para as quais tenham sido concedidos benefícios em desacordo com o previsto na alínea "g" do inciso XII, do $\S 2^{\circ}$, do art. 155, da Constituição Federal, e na Lei Complementar Federal n ${ }^{\circ} 24$, de 7 de janeiro de 1975, o contribuinte adquirente mineiro ou o substituto tributário, inclusive o localizado em outra unidade da Federação, deverá observar o disposto neste decreto.

AR.1 - Anistia com remissão.

Exemplo: Lei PB 11.707, de 2020. Ficam concedidas remissão e anistia dos créditos tributários, constituídos ou não, inscritos ou não em dívida ativa, inclusive os espontaneamente denunciados pelo contribuinte, ainda que ajuizados, decorrentes dos benefícios fiscais, previstos nos itens 33 e 34, do Anexo Único, da Lei no 11.308, de 8 de abril de 2019.

\section{Parcelamento e parcelamento incentivado}

P.1 - Parcelamento prazo ordinário extralongo.

Exemplo: $\S 1^{\circ}$, do art. $1^{\circ}$, do Decreto BA 7798 de 2000: poderá, ainda, o Fundo de Fomento e Desenvolvimento Socioeconômico (Fundese) financiar o pagamento de impostos incidentes na importação de produtos destinados à comercialização e industrialização promovidas por novas indústrias instaladas no Estado.

P.2 - Parcelamento financeiramente beneficiado.

Exemplo: art. $3^{\circ}$, da Lei AL 5901, de 1997: o financiamento obtido a título de incentivo creditício, de que trata o art. $4^{\circ}$, inciso III, alínea a, da Lei $\mathrm{n}^{\mathrm{o}} 5.671$, de $1^{\circ}$ de fevereiro de 1995 , será reposto pelo valor originariamente tomado, sobre ele não incidindo juros ou atualização de qualquer espécie. 
P.4 - Parcelamento incentivado - Combo.

Exemplo: Art. 2º inciso II, da LC PE 362, de 2017: redução do crédito tributário corresponde aos seguintes percentuais na hipótese de pagamento parcelado, em até 36 (trinta e seis) parcelas mensais e sucessivas $60 \%$ (sessenta por cento) da multa e $70 \%$ (setenta por cento) dos juros.

P.5 - Parcelamento prazo regulamentar longo.

Exemplo: art. $1^{\circ}$, do Decreto CE 22.083, de 1992: o recolhimento do ICMS pelos estabelecimentos industriais de embalagens flexíveis de polietileno e polipropileno, relativo aos fatos geradores ocorridos nos meses de julho a dezembro de 1992, poderá realizar-se até 120 (cento e vinte) dias após o respectivo período de apuração.

\section{Devolução total ou parcial}

D.1 - Devolução total ou parcial do valor do ICMS recolhido.

Exemplo: Lei ES 2508, de 1970 e Lei ES 9937, de 2012, combinadas com art. $2^{\circ}$, do Decreto ES 3174, de 2012: o financiamento relativo às operações realizadas ao amparo da Lei n. ${ }^{\circ} 2.508$, de 1970, terá valor equivalente a $3 \%$ (três por cento) da operação de que decorrer da saída de mercadorias do estabelecimento importador, correspondente a 75\% (setenta e cinco por cento) do imposto recolhido, nas operações com alíquota do ICMS igual a $4 \%$ (quatro por cento).

\section{Subsídio fiscal ou financeiro}

SF.1 - Vantagem financeira concedida pelo Estado tributante ao contribuinte, desde que observadas certas condições, que não sejam relacionadas, direta ou indiretamente, ao ICMS pago ou devido.

Exemplo: Lei RJ 3578, de 2001, Anexo, Cláusula Segunda, Item 2.2, "a": conceder à Cintra financiamento de capital de giro, no valor equi- 
valente a $30 \%$ (trinta por cento) da receita total de vendas mensal, em parcelas mensais e sucessivas, limitadas a 75\% (setenta e cinco) dos impostos estaduais incrementais, próprios e retidos, recolhidos em favor do Estado do Rio de Janeiro, no mesmo mês de referência do faturamento, com prazo de fruição de 13 (treze) anos, a contar da data da primeira operação de venda, e prazo de amortização de 13 (treze) anos, contados após o prazo de utilização e carência, e incidência de juros nominais de 3\% (três por cento) ao ano.

\section{Outros incentivos fiscais}

RE.1. - Regime especial de percentual sobre as vendas.

Exemplo: Lei RJ 4531, de 2005, artigo $2^{\circ}$ : o estabelecimento industrial enquadrado nos setores de atividade de que trata o artigo $1^{\circ}$ desta Lei, poderá recolher o ICMS, equivalente a $2,5 \%$ sobre o faturamento realizado no mês de referência, sendo que a utilização da sistemática de apuração a que refere este artigo veda o aproveitamento de qualquer crédito do ICMS.

\section{APÊNDICE II}

Exemplos de cálculo do gasto tributário

\section{I.1.1 Isenção básica}

Alíquota de ICMS de 18\% (dezoito por cento).

Isenção de ICMS na venda do produto X no varejo ao consumidor final (não contribuinte do ICMS) no valor de R\$1.000,00, sem manutenção dos créditos de ICMS incidente na aquisição do produto X. Produto X adquirido pelo varejista pelo valor de R \$ 700,00, sem isenção de ICMS. 
(1) ICMS na venda do produto X pelo varejista $=18 \% \mathrm{x} \$ 1.000,00$ $=\mathrm{R} \$ 180,00$;

(2) ICMS na aquisição do produto $\mathrm{X}$ pelo varejista $=18 \% \mathrm{x} \mathrm{R}$ $700,00=\mathrm{R} \$ 126,00$;

(I) ICMS que seria recolhido, se não houvesse isenção $=(1)-(2)=$ $\mathrm{R} \$ 180,00-\mathrm{R} \$ 126,00=\mathrm{R} \$ 54,00$;

(II) ICMS recolhido com a isenção $=\mathrm{R} \$ 0,00$;

(III) Crédito acumulado para abater do ICMS sobre vendas de outros produtos do varejista $=\mathrm{R} \$ 0,00$;

Gasto tributário $=(\mathrm{I})-(\mathrm{II})+(\mathrm{III})=\mathrm{R} \$ 54,00-\mathrm{R} \$ 0,00-\mathrm{R} \$ 0,00$ $=\mathrm{R} \$ 54,00$;

Observação: o varejista deixa de recolher R\$ 54,00 ([1] - [2]) de ICMS e perde o direito de utilizar o crédito de ICMS de R $\$ 126,00$ (2).

\section{I.1.2 Isenção ampliada}

Alíquota de ICMS de 18\% (dezoito por cento).

Isenção de ICMS na venda do produto X no varejo ao consumidor final (não contribuinte do ICMS) no valor de $\mathrm{R} \$ 1.000,00$, com manutenção dos créditos de ICMS incidente na aquisição do produto X. Produto X adquirido pelo varejista pelo valor de R $\$ 700,00$, sem isenção de ICMS.

(1) ICMS na venda do produto X pelo varejista $=18 \% \times \mathrm{R} \$ 1.000,00$ $=\mathrm{R} \$ 180,00$;

(2) ICMS na aquisição do produto $X$ pelo varejista $=18 \% \times R \$$ $700,00=\mathrm{R} \$ 126,00$;

(I) ICMS que seria recolhido, se não houvesse isenção $=(1)-(2)=$ $\mathrm{R} \$ 180,00-\mathrm{R} \$ 126,00=\mathrm{R} \$ 54,00$;

(II) ICMS recolhido com a isenção $=\mathrm{R} \$ 0,00$;

(III) Crédito acumulado para abater do ICMS sobre vendas de outros produtos do varejista $=\mathrm{R} \$ 126,00$; 
Gasto tributário $=(\mathrm{I})-(\mathrm{II})+(\mathrm{III})=\mathrm{R} \$ 54,00-\mathrm{R} \$ 0,00+\mathrm{R} \$$ $126,00=\mathrm{R} \$ 180,00$.

Observação: o varejista deixa de recolher R \$ 54,00 ([1] - [2]) de ICMS, mas mantém o direito de utilizar o crédito de ICMS de R \$126,00 (2).

\section{I.2.1 Pseudobenefício}

Alíquota de ICMS de 18\% (dezoito por cento).

Isenção do produto $\mathrm{X}$ na venda de atacadista para varejista (contribuinte do ICMS) no valor de $\mathrm{R} \$ 1.000,00$, sem manutenção do crédito de ICMS incidente na aquisição do produto $\mathrm{X}$ pelo atacadista. Produto $\mathrm{X}$ adquirido pelo atacadista pelo valor de R $\$ 700,00$, sem isenção de ICMS.

$\mathrm{O}$ varejista vende o produto $\mathrm{X}$, sem isenção do ICMS, pelo valor de $\mathrm{R} \$ 1.500,00$.

(1) ICMS na venda do produto $\mathrm{X}$ pelo atacadista $=18 \% \times \mathrm{R} \$$ $1.000,00=\mathrm{R} \$ 180,00$;

(2) ICMS na aquisição do produto $\mathrm{X}$ pelo atacadista $=18 \% \times \mathrm{R} \$$ $700,00=\mathrm{R} \$ 126,00$;

(3) ICMS na venda do produto X pelo varejista $=18 \% \times \mathrm{R} \$ 1.500,00$ $=\mathrm{R} \$ 270,00$;

(4) ICMS na aquisição do produto X pelo varejista $=18 \% \times \mathrm{R} \$$ $1.000,00=\mathrm{R} \$ 180,00$;

(I) ICMS que seria recolhido se não houvesse isenção (atacado + varejo $=(1)-(2)+(3)-(4)=R \$ 180,00-R \$ 126,00+R \$ 270,00-R \$$ $180,00=\mathrm{R} \$ 144,00$;

(II) ICMS recolhido com a isenção $($ atacado + varejo $)=(3)=\mathrm{R} \$$ 270,00 ;

(III) Crédito acumulado para abater do ICMS de vendas de outros produtos (atacadista + varejista $)=\mathrm{R} \$ 0,00$; 
Gasto tributário $($ negativo $) \Rightarrow($ ganho tributário $)=(\mathrm{I})-(\mathrm{II})+(\mathrm{III})$ $=\mathrm{R} \$ 144,00-\mathrm{R} \$ 270,00+\mathrm{R} \$ 0,00=-\mathrm{R} \$ 126,00$;

Observação: o atacadista deixa de recolher R \$ 54,00 ([1] - [2]) de ICMS e perde o direito de utilizar o crédito de ICMS de R\$126,00 (2).

O varejista perde direito ao crédito de $\mathrm{R} \$ 180,00$ (4) na aquisição do atacadista. Independente da sua aquisição ser isenta ou não, o varejista terá de pagar o ICMS sobre a venda (3), pois esta não possui benefício sobre o ICMS.

\section{I.2.2 Combinado com I.1.1}

Alíquota de ICMS de 18\% (dezoito por cento).

Isenção do produto $\mathrm{X}$ na venda de atacadista para varejista (contribuinte do ICMS) no valor de R $\$ 1.000,00$, sem manutenção do crédito de ICMS incidente na aquisição do produto X pelo atacadista. Produto X adquirido pelo atacadista pelo valor de $\mathrm{R} \$ 700,00$, sem isenção de ICMS.

Isenção de ICMS na venda do produto $\mathrm{X}$ no varejo a consumidor final (não contribuinte do ICMS) no valor de R \$1.500,00. Não há crédito na aquisição pelo varejista, já que essa operação também é isenta.

(1) ICMS na venda do produto $\mathrm{X}$ pelo atacadista $=18 \% \times \mathrm{R} \$$ $1.000,00=\mathrm{R} \$ 180,00$;

(2) ICMS na aquisição do produto $\mathrm{X}$ pelo atacadista $=18 \% \times \mathrm{R} \$$ $700,00=\mathrm{R} \$ 126,00$;

(3) ICMS na venda do produto X pelo varejista $=18 \% \times \mathrm{R} \$ 1.500,00$ $=\mathrm{R} \$ 270,00$;

(4) $\mathrm{ICMS}$ na aquisição do produto $\mathrm{X}$ pelo varejista $=18 \% \times \mathrm{R} \$$ $1.000,00=\mathrm{R} \$ 180,00$;

(I) ICMS que seria recolhido se não houvesse isenção (atacado + varejo $)=(1)-(2)+(3)-(4)=R \$ 180,00-R \$ 126,00+R \$ 270,00-R \$$ $180,00=\mathrm{R} \$ 144,00$; 
(II) ICMS recolhido com a isenção (atacado + varejo) $=0,00$;

(III) Crédito acumulado para abater do ICMS de vendas de outros produtos $($ atacadista + varejista $)=\mathrm{R} \$ 0,00$;

Gasto tributário $=(\mathrm{I})-(\mathrm{II})+(\mathrm{III})=\mathrm{R} \$ 144,00-\mathrm{R} \$ 0,00+\mathrm{R} \$ 0,00$ $=\mathrm{R} \$ 144,00$.

Observação: o atacadista deixa de recolher R \$ 54,00 ([1] - [2]) de ICMS e perde o direito de utilizar o crédito de ICMS de R $\$ 126,00$ (2).

O varejista deixa de recolher R\$90,00 ([3] - [4]) de ICMS e não tem direito de utilizar o crédito de ICMS de R\$ 180,00 (4) em razão da aquisição ter sido isenta.

\section{I.2.3 Isenção diferimento}

Alíquota de ICMS de 18\% (dezoito por cento).

Isenção do produto $\mathrm{X}$ na venda de atacadista para varejista (contribuinte do ICMS) no valor de R\$1.000,00, com manutenção do crédito de ICMS incidente na aquisição do produto X pelo atacadista. Produto X adquirido pelo atacadista pelo valor de R $\$ 700,00$, sem isenção de ICMS.

$O$ varejista vende o produto $X$, sem isenção do ICMS, pelo valor de $\mathrm{R} \$ 1.500,00$.

(1) ICMS na venda do produto $\mathrm{X}$ pelo atacadista $=18 \% \mathrm{x} \mathrm{R}$ $1.000,00=\mathrm{R} \$ 180,00$;

(2) ICMS na aquisição do produto $\mathrm{X}$ pelo atacadista $=18 \% \times \mathrm{R} \$$ $700,00=\mathrm{R} \$ 126,00$;

(3) ICMS na venda do produto X pelo varejista $=18 \% \times \mathrm{R} \$ 1.500,00$ $=\mathrm{R} \$ 270,00$;

(4) ICMS na aquisição do produto $\mathrm{X}$ pelo varejista $=18 \% \times \mathrm{R} \$$ $1.000,00=\mathrm{R} \$ 180,00$;

(I) ICMS que seria recolhido se não houvesse isenção (atacado + varejo $)=(1)-(2)+(3)-(4)=R \$ 180,00-R \$ 126,00+R \$ 270,00-R \$$ 
$180,00=\mathrm{R} \$ 144,00$

(II) ICMS recolhido com a isenção (atacado + varejo $)=(3)=\mathrm{R} \$$ 270,00;

(III) Crédito acumulado para abater do ICMS de vendas de outros produtos $($ atacadista + varejista $)=\mathrm{R} \$ 126,00$;

Gasto tributário $=(\mathrm{I})-(\mathrm{II})+(\mathrm{III})=\mathrm{R} \$ 144,00-\mathrm{R} \$ 270,00+\mathrm{R} \$$ $126,00=\mathrm{R} \$ 0,00$.

Observação: o atacadista deixa de pagar R \$ 54,00 ([1] - [2]) de ICMS, mas mantém o direito de utilizar o crédito de ICMS de R\$126,00 (2).

O varejista perde direito ao crédito de $\mathrm{R} \$ 180,00$ (4) na aquisição do atacadista. Independente da sua aquisição ser isenta ou não, o varejista terá de pagar o ICMS sobre a venda (3), pois esta não possui benefício sobre o ICMS. 